\title{
Statewide farmland protection is fragmented, limited
}

\author{
Steve Sanders
}

\begin{abstract}
Fueled by a search for affordable land to house 600,000 new California residents each year, conversion of farmland to development has proceeded at a rapid pace
\end{abstract} since 1950. The impact of growth and development on open space and agricultural land is a critical issue for a very simple reason: the areas best suited for cropland - those favored by good weather, flat terrain and access to water are also the areas most in demand for new homes and businesses. If meaningful farmland protection is to be enacted, California's farm community itself must become more united and aggressive, forming a broad coalition with water suppliers, environmentalists, local officials, and business and community leaders.

alifornia's population increased at a record-setting pace in the 1980 s, growing $25 \%$ in one decade. The state's Department of Finance expects

The Discovery Bay development and golf course abut Delta farmland; the state has recently created the Delta Protection Commission to stem farmland loss. Photo by Jack Kelly Clark. a net increase of 6 million residents in the next 10 years (Heim 1997) - more people with a growing demand for land development. Yet California is ill-prepared to manage the impacts of another burst of rapid growth.

Perhaps no component of the state's economy is at greater risk from growth than is agriculture. Farmland has been converted to development at a rapid clip. As urbanization proceeds, major conflicts arise. For example, the demands of a growing urban population and economy, coupled with a belated effort to reverse decades of ecological decline in the state's rivers, lakes and wetlands, has placed an enormous strain on scarce water supplies, creating pressure to divert water from farms in order to serve cities and the environment (Goldman 1991, Reisner 1997).

\section{California's growth}

California's farmlands face five major threats related to growth.

The loss of agricultural land. From the early 1970s through the present, between 50,000 and 100,000 acres of land were estimated to be urbanized annually in the state (Nisbet 1993,
In traditionally pro-growth Contra Costa County, 5,330 homes were planned for Tassajara Valley. Under pressure from community residents opposed to urban sprawl, developers withdrew their proposal in May.

\section{THE LARGER COLLECTION . .}

The articles in this issue are condensed from several articles in an upcoming book, California Farmland and Urban Pressures: Statewide and Regional Perspectives, to be published by the UC Agricultural Issues Center later this year. Al Medvitz and Al Sokolow have edited the book, and its diverse authors include farm operators, citizen activitists, planning experts and UC faculty.

The larger collection will include 10 papers and an introduction. As well as expanded versions of the five papers and the sidebar on population trends in this issue of California Agriculture, the larger collection will include studies of (1) farmland politics in the Central Valley; (2) agricultural and land-use trends over time; (3) the politics of farmland protection in Napa and Marin counties; and (4) urbanization and natural resources in the northern Sacramento Valley.

To order the forthcoming book, call Sandy Fisher at (530) 752-1520. 


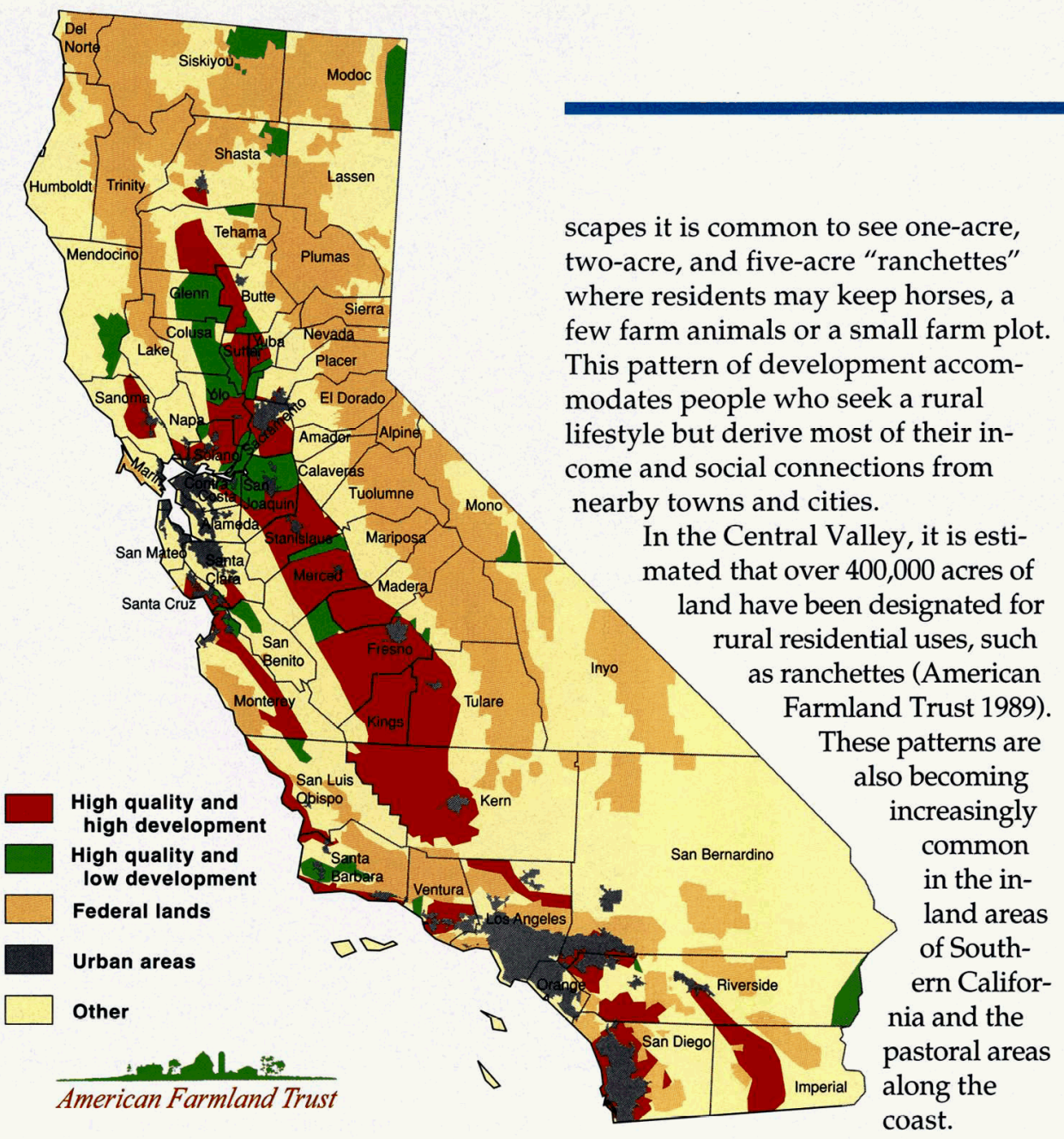

This map highlights geographic areas using two threshold tests that define the importance and vulnerability of the land: - High quality farmland is that which in 1992 had relatively large amounts of prime farmland or specialty crop land.

- High development areas are those that experienced relatively rapid development between 1982 and 1992.

- Other areas are those that do not meet the two threshold tests, and that are neither federal lands nor urban areas.

Grossi 1993). Much of this development occurred on cropland (see sidebar, p. 8).

In the 1960s, 1970s and early 1980s, most of the new development took place near the coast. In response, many agricultural enterprises fled the coast for the Chino Hills, Imperial, Riverside and San Bernardino counties, and the great Central Valley. Now, each of these areas is among the fastest-growing regions in the state, and California agriculture literally has nowhere else to go (Heim 1997).

The "rurbanization" of the working landscape. In many rural land- scapes it is common to see one-acre, two-acre, and five-acre "ranchettes" where residents may keep horses, a few farm animals or a small farm plot. This pattern of development accommodates people who seek a rural come and social connections from nearby towns and cities.

In the Central Valley, it is estimated that over 400,000 acres of have been designated for ural residential uses, such ranchettes (American These patterns are also becoming coasingly in the inland areas of Southern Califoralong the coast.

As more people are introduced into an area, the conflicts between residents and the realities of farm life, with its noise, odors and chemicals, increase. Farm practices become more controversial and restricted. Land costs may rise, as the underlying value begins to reflect the higher return of developed uses, fostering yet more land conversion.

Water tug of war. There is general consensus that California has moved from an era of water development to one of water management (Goldman 1991, Reisner 1997). While some incremental increases in supply and conveyance facilities can be made, the water system we have in place today is the basic system we will have for the foreseeable future.

The result is a three-way tug of war between agriculture, urban centers and the environment for California's limited supply of water. As new water storage and conveyance facilities are built, old water supply contracts are renegotiated, and maintenance costs mount, the average cost of water denia and the livered to the fields rises while the reliability of receiving full water delivery allotments declines. Cities can pay the price, especially when water is scarce, and spread it over their large rate-payer base. Farmers, quite often, cannot.

Public works paving the way for urbanization. Growth tends to follow the facilities available to service it (Misczynski 1987). The mere existence of a major public facility with unallocated capacity such as a freeway, water system or sewer system tends to act as a magnet for new development. Hence, large freeway interchanges in rural or low-density suburban areas accessible to existing urban centers become nodes for new "edge city" office parks and subdivisions, whether there was ever a plan or intent to urbanize the area.

In essence, public decisions on the size, character and location of major public facilities become a major determinant of future patterns of urban development. Because the potential impacts of these decisions on agricultural land are too often not understood or not considered by public officials, the long-term viability of the agricultural economy is placed at risk.

The very high initial cost of providing such facilities often forces the urbanization of the area, in order to provide the underlying economic value to pay for the facilities. This is especially true given current practices to pay for infrastructure through assessment districts, development fees and other value-capture mechanisms rather than general public revenues (Misczynski 1987, 1992).

Fiscal pressures for farmland conversion. California allocates property and sales tax revenue back to the local jurisdictions where they originate. Since these revenues are not allocated on a per capita basis, they may bear little or no relationship to the costs of providing needed services and facilities to accommodate development. The state has made matters worse by shifting a large and growing share of local property taxes from cities, counties and special districts to schools 
(that share is now about $\$ 3.5$ billion annually) - thereby relieving the state's General Fund of a large portion of its obligation to fund education as mandated under Proposition 98.

Local communities have used many strategies to respond to this dilemma, including a growing use of development fees, ballot measures to override tax and spending caps, and most importantly, competition for revenueproducing development. Counties and cities compete in an increasingly desperate effort to attract revenueproducing development with low service needs, such as auto malls and bigbox retailers, while avoiding land uses that create ongoing costs for expensive public services, particularly housing affordable to middle-income or lowerincome families.

This "fiscalization of land use" (Misczynski 1987) affects agriculture adversely in three ways. First, cities push to include large swaths of agricultural land in their spheres of influence (the area expected to eventually be incorporated within the city limits) so that they may be annexed in the future. This signals the market to raise land prices in anticipation of development, shifting the economic calculus away from long-term agricultural use (see p. 23). Secondly, as areas on the urban fringe are developed, farmlands are assessed part of the cost of infrastructure. This happens through rising property taxes (due to higher land values) and through assessments to pay for new infrastructure. All add to the economic pressure for conversion.

Finally, counties, which are usually the units of government most protective of farmland, feel obliged to engage in the development game as well, if only to preclude cities from capturing the economic windfalls (such as sales and propery taxes) while shifting the burdens (such as traffic and cost of infrastructure) to others. As a consequence, the commitment of county leaders to agricultural protection weakens over time as new areas of the county are opened to development.

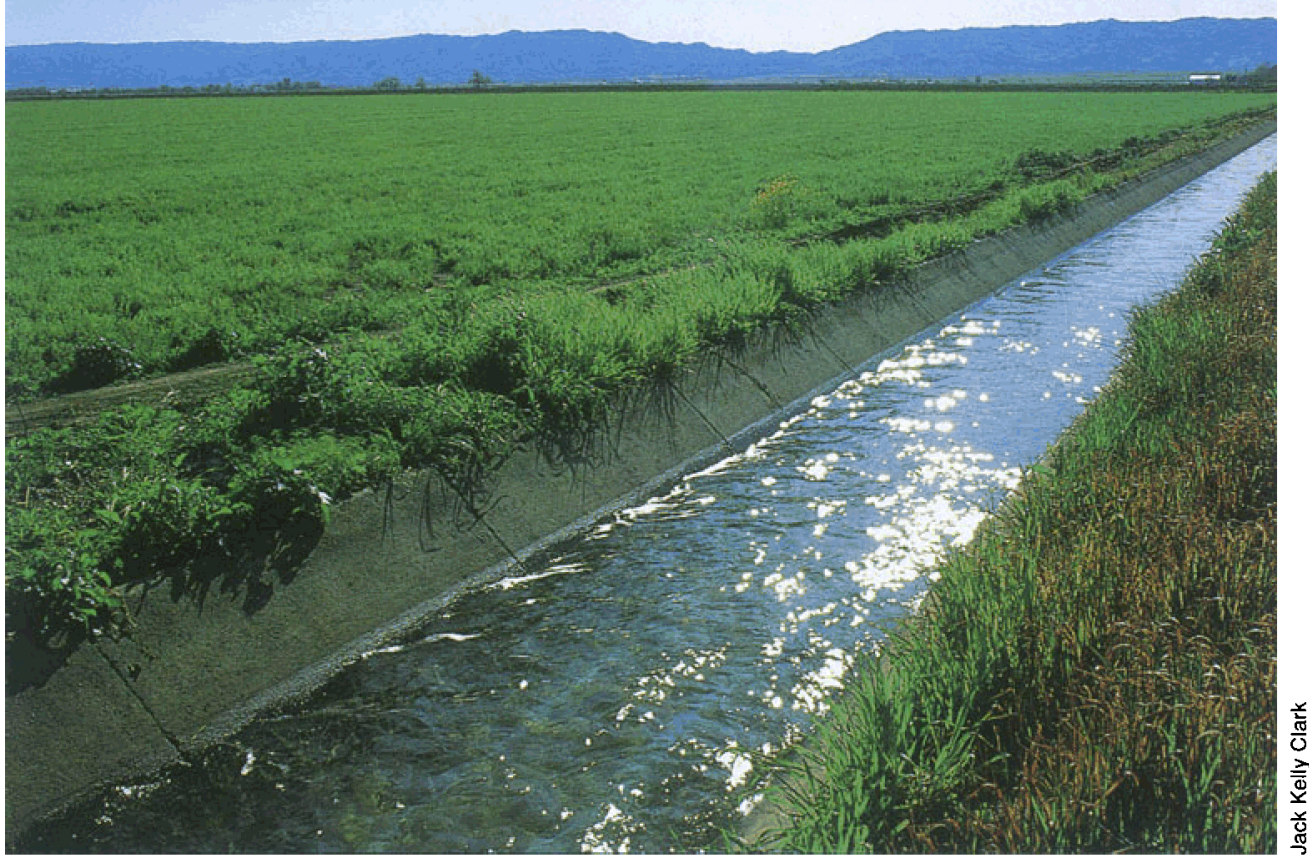

Farmers rely on an abundant supply of reasonably priced water. However, the average cost of water delivered to fields is rising while the reliability of receiving water declines. Above, a concrete irrigation ditch near Winters in Yolo County.

\section{State policy responses}

State policies for agriculture, open space and natural systems stress conservation. These policies can and do conflict with one another - such as restrictions on farming practices to protect endangered species, or diversion of water to farms that cause fisheries to decline precipitously.

Program responsibilities to carry out farmland preservation policies are divided among local communities (see p. 17 ) and the state. State responsibilities focus on data, review of local actions and funding for conservation programs. Local agencies are much more powerful, with direct authority to make land-use decisions and primary responsibility for implementing specific resource conservation projects and programs.

\section{California's farmland protection}

Direct land conservation is carried out primarily through local and regional agricultural land trusts (see p. 27). These trusts can purchase land outright, but more commonly acquire easements to preclude development on agricultural land. Proposition 70 of 1988 provided state bond funding to a number of land trusts throughout the state for these programs.

While some land trusts, such as those operating in Marin, Sonoma and Napa counties, have been successful in protecting locally important agricultural areas, land trusts to date have had only a minor impact on statewide farmland conversion. Well below $1 \%$ of California land is in public or private land trusts, and a small fraction of that is agricultural land.

Tax relief for agricultural property is provided through the Williamson Act, which assesses property taxes at a reduced rate on land which owners pledge to retain in agricultural use for 10 years. The rate reflects the land's value for farming rather than development.

While the Williamson Act provides a useful tool to encourage long-term agricultural use of the land and discourage leap-frog and remote development, the program appears to have had only a marginal success in stemming the conversion of the most vulnerable farmland to urban uses. Farmers may use the 10-year period to transition out of farming and into development, and much of the acreage enrolled in the program is remote 


\section{Urban growth squeezes agriculture}

\section{Albert G. Medvitz}

A century ago, the state was populated by 1 million Californians about the same number who now attend the Rose Bowl Parade every Jan. 1.

Today's state population is 33 times greater. The Department of Finance recently reported a $1.8 \%$ increase for the year ending July 1997 - 574,000 more people. The numbers signaled a resurgence of net migration and continuing high rate of natural increase. The same figures showed that all but four counties grew, and Monterey and San Benito counties tied for the state's highest growth, at $4.9 \%$.

Rapid growth is a century-long trend in California (fig. 1). Since the time of the Gold Rush, California's

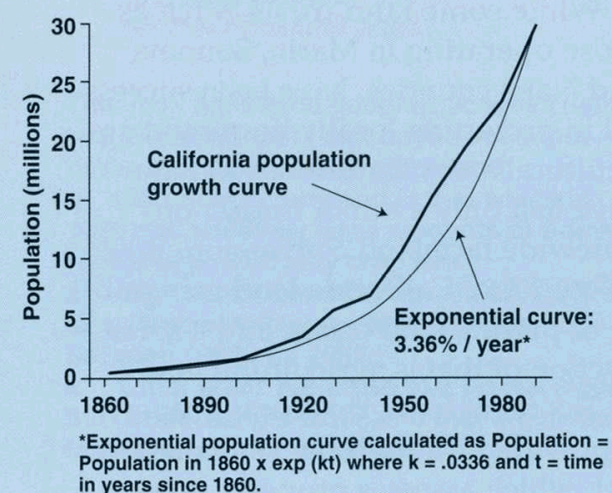

Fig. 1. California population growth, 1860-1990.

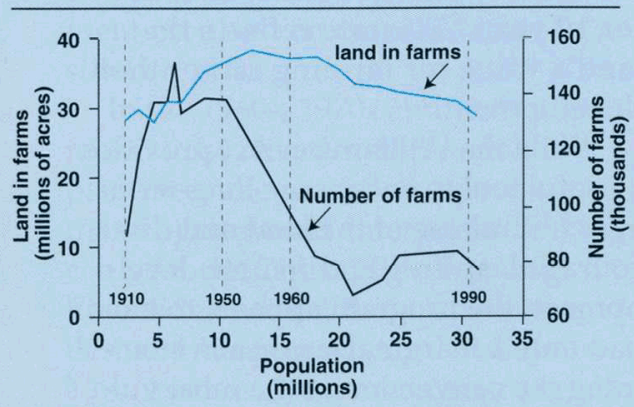

Fig. 2. Number of farms and land in farms versus population, 1910 to 1992. Source: U.S. Census Bureau, Censuses of Agriculture. average yearly growth has exceeded $3.36 \%$ per year. Even when growth slowed during the recession of the early 1990s, California's fastest growing counties topped the growth rate of most countries in the world (table 1).

In recent decades, urban growth has led to farmland losses and changing economics for a number of farms. According to U.S. Bureau of the Census figures, the state lost close to 9 million acres of farmland between 1950 and 1993, a decline of almost 25\%, from about 38 million to 29 million acres. As California's population continues to grow, so will urban land. By 2100, if current land-use patterns don't change, urban land in California could occupy one-third of the state - more area than is currently occupied by agriculture.

\section{The reverse of a trend}

For the first half of this century, farms and farmland increased along with California's population growth. But after 1950, the trend reversed. As population increased further, farmland declined (fig. 2). Urban populations moved into the agricultural midcoastal valleys of Ventura and Monterey and San Luis Obispo and the fertile valleys east, north and south of San Francisco, dramatically transforming the landscape. Aerial photographs (see p. 9) show the consequences of this trend for the Santa Clara Valley.

Nevertheless, the volume of agricultural production has continued to increase to the present. Farmland losses were countered after World War II by massive irrigation projects such as the Central Valley Project, which allowed the expansion of intensive irrigated agriculture into otherwise arid grazing lands in the Southern San Joaquin Valley. Growers continued to adopt new technologies and crops, and further diversified, expanding from 200 commodities at the end of
World War II to 350 crop and livestock commodities by 1996 .

Despite increasing production, markets changed such that the value of the state's agricultural production experienced an extended decline after 1975, if figures are adjusted for inflation. In constant 1992 dollars, the 1975 value of production was $\$ 25$ billion and the 1993 value of production was $\$ 18$ billion. Production value has shown an upward trend in the past 5 years.

\section{What lies ahead?}

More recently, population has spread over the Tehachapis south of Bakersfield and over the coastal ranges into the fertile Central Valley. This time agriculture has nowhere to go. The children of dairy farmers who sold their San Bernadino operations and resettled in the Central Valley don't have the same options their parents had, because additional dairy land is not readily available in the state. Relo-

TABLE 1. Five-year average of population growth rates of selected countries, California and selected California counties, 1990-1995

$\begin{array}{llll}\text { Imperial } & 4.4^{\star} & \text { Orange } & 2.0 \\ \text { Israel } & 3.8 \dagger & \text { Bangladesh } & 2.0 \\ \text { Madera } & 3.5 & \text { India } & 1.9 \\ \text { Peru } & 3.3 & \text { San Bernadino } & 1.9 \\ \text { Saudi Arabia } & 3.0 & \text { Haiti } & 1.8 \\ \text { Nigeria } & 2.9 & \text { Brazil } & 1.6 \\ \text { Kenya } & 2.8 & \text { California } & 1.4 \\ \text { Afghanistan } & 2.8 & \text { Santa Clara } & 1.3 \\ \text { Riverside } & 2.8 & \text { Argentina } & 1.2 \\ \text { Zimbabwe } & 2.6 & \text { China } & 1.1 \\ \text { Kern } & 2.3 & \text { Los Angeles } & 1.0 \\ \text { South Africa } & 2.3 & \text { United States } & 1.0 \\ \text { Fresno } & 2.3 & \text { Switzerland } & 1.0 \\ \text { Vietnam } & 2.2 & \text { France } & 0.5 \\ \text { Tulare } & 2.2 & \text { Japan } & 0.3 \\ \text { Ecuador } & 2.1 & \text { Great Britain } & 0.3 \\ \text { Stanislaus } & 2.0 & \text { Russia } & 0.1 \\ \text { Mexico } & 2.0 & \text { Italy } & 0.1\end{array}$

* California and county rates, shown in blue, are mean yearly rates calculated for 1990-1995. They are somewhat less than 1980-1990 averages and are based on Department of Finance estimates rather than US census counts.

+ Country estimates are 1990-1995 averages from the World Bank's World Population Projections: 1994-95. 
cating orchards is no longer simple because there is less easily irrigated flat land.

In addition, there are no more massive irrigation projects to turn deserts into fertile plains. Finally, urban populations now wish to preserve landscape for aesthetic and recreational purposes, as well as to enhance habitat for native creatures, purposes which may not be compatible with productive agriculture.

We are not yet close to losing the state's agricultural productivity. With a $\$ 24.5$ billion farmgate value in 1996, agriculture remains a vital industry, and with $68 \%$ of its production exported (55\% to other states), agriculture is an important economic contributor to local, state and national economies.

But we are faced with the prospect of huge dislocations and management dilemmas. For instance, agricultural employment remains critical to the economies of certain regions, most notably the San Joaquin Valley, where farm-related industries directly employ $8.5 \%$ of the total employees in all economic sectors. Central Valley farmland is the target of much planned population growth. If current trends continue, almost one-third of its irrigated cropland could be urbanized by 2040 (see map, p. 20). How do we accommodate new people in agricultural areas and maintain our productivity? How do we plan and manage for a future with many more people making increasing and conflicting demands on the state's land resources?

If agriculture is to have a long-term future in this state, we must acquire a better understanding of local land-use decision-making, as well as how, when and where the state's population is growing, and its agricultural impacts. Only then can we provide researchbased information that will enable localities to make effective decisions concerning this important resource.

A.G. Medvitz, a rancher in Solano County, has an Ed.D. degree from Harvard University in Administration, Planning and Social Policy. from the urban edge where development pressures - and the benefits of the program - are greatest.

Constraints on incorporation and annexation of farmland are contained in the CorteseKnox Act and other state laws. Many policies are directly and indirectly related to land conservation, including an explicit directive to protect farmland from unwarranted conversion.

These general state policies are overseen by Local Agency Formation Commissions (LAFCOs) in each county, composed of city, county and public members. However, LAFCOs have no direct authority over land use, and cannot override city or county decisions regarding development applications. Also, LAFCOs rarely reject an annexation or incorporation proposal championed by a local community based on its impacts on farmland, and become mired in controversy when they do act to protect agricultural land.

Agriculture is typically included in the local general plan, in either the state-mandated land use or open space elements, or an optional agricultural element. However, state law does not impose any meaningful substantive requirements that local governments actually protect or preserve agricultural land in the face of development pressures. Instead, California's strong tradition of local home rule grants individual cities and counties wide discretion over land use and development decisions, which they often exercise to allow the conversion of farmland to urban uses.



Above, Santa Clara County in 1950 is mainly fruit and nut orchards and a few row crops. Below, in 1980, the same land is covered by the rapidly growing suburbs of San Jose.

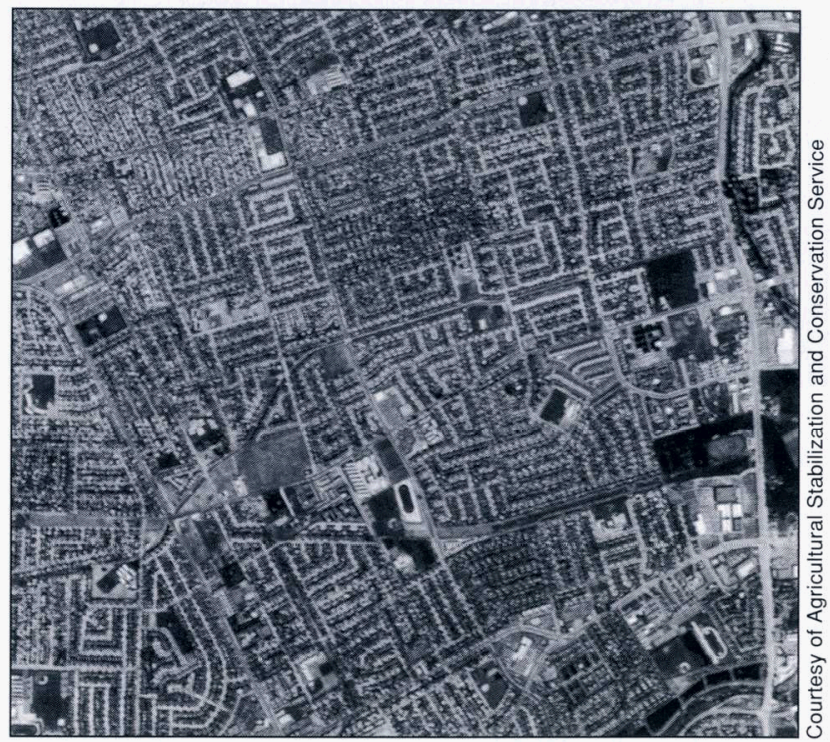

The California Environmental Quality Act (CEQA) is perhaps the preeminent state environmental statute in the nation. However, the act has several weaknesses when it comes to protecting farmland. Farmland conversion per se is not considered a "significant environmental impact" under CEQA. As a consequence, many farmland conversion actions escape environmental scrutiny altogether. Even when significantly adverse farmland impacts are identified, lead agencies are free to approve a project by making a finding that the benefits of the project outweigh the impacts, or by deciding that alternatives to the project 


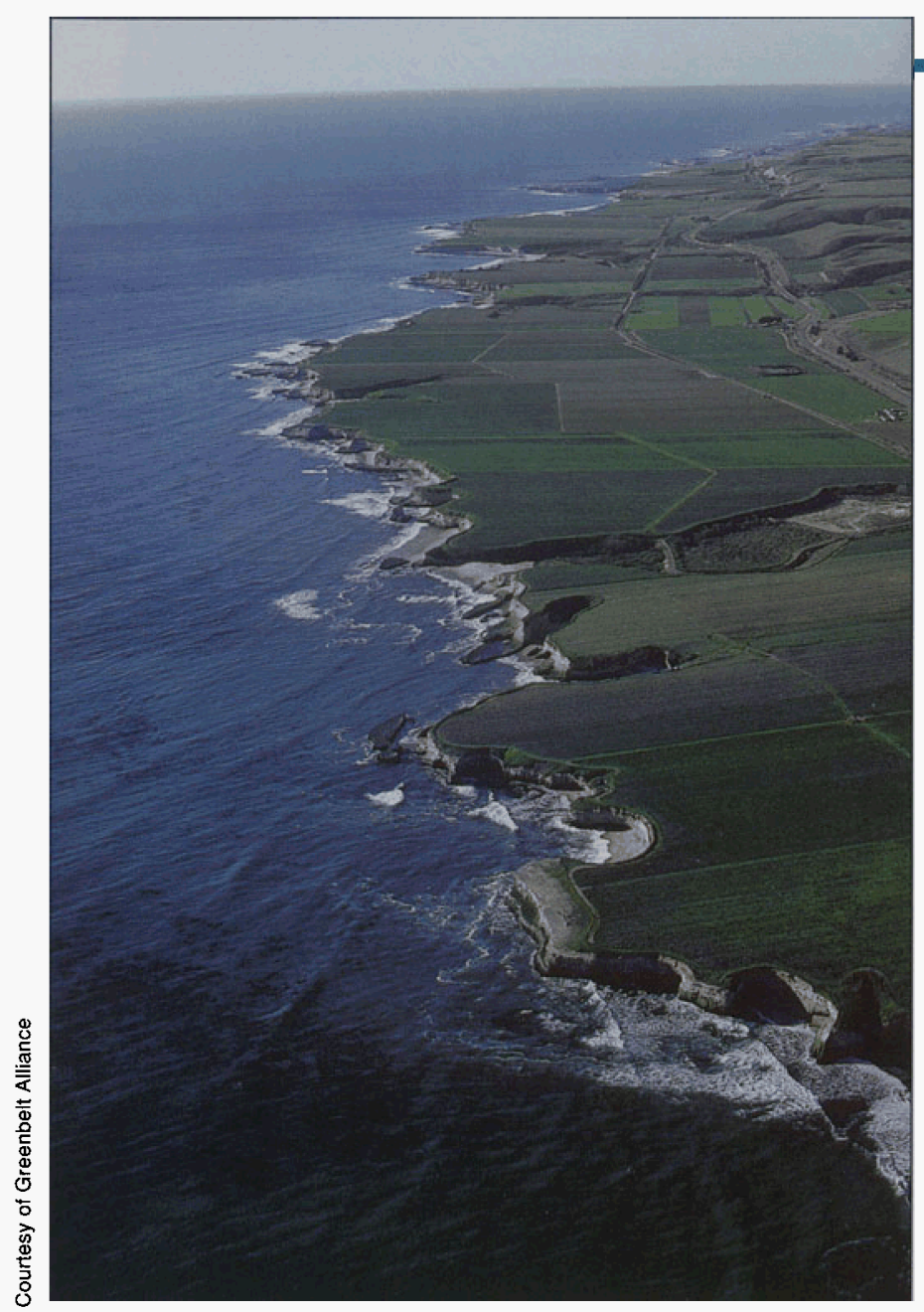

In 1986 San Mateo County voters approved a ballot measure to protect their coast, including local farms, from development.

or mitigation measures intended to lessen the impact are "infeasible."

Perhaps the state decisions most profoundly affecting farmland are those that impact the location, pace and timing of suburban and rural development and, with it, the pressure for farmland conversion. Such decisions concern water supply, water quality, freeway routes, university campus and state prison locations, priorities for school construction and renovation, and flood protection, among other issues.

For the most part, these decisions are made in an uncoordinated manner that lacks a unifying vision or comprehensive approach to planning and development.

\section{The politics of farmland protection}

Given the serious threats to the fundamental underpinning of California's
$\$ 24.5$ billion agricultural economy - the land itself - why isn't state government doing more to ensure a stronger and more effective state farmland protection policy? One key explanation is that the forces committed to farmland protection are too weak, fragmented, and isolated to secure sufficient political support for the enactment and effective implementation of meaningful farmland protection programs.

Perhaps most importantly, the agricultural community itself is split. While groups such as the American Farmland

Trust and the California Farm Bureau Federation promote agricultural protection, individual county farm bureaus and commodity groups are often divided. Many farmers and their heirs see the land as their greatest asset, and are loath to give up the potential benefits of converting the land for development. Lacking a unified voice, agriculture is often in a weak position to advocate strong farmland protection measures at the state level.

Secondly, the economic and political power of the land development industry is formidable. Large sectors of the building industry have come to rely on the economic return that accrues from purchasing farmland cheaply and then persuading local officials to change the allowable uses.

Environmentalists are often at odds with the farm industry in California. Fights over water for farms versus water for fish and wildlife have been especially bitter, protracted and divisive. Disputes over agricultural runoff, pesticide use and agricultural burning only add to the animosity and distrust. These conflicts make it extremely difficult to establish farmer-environmen- talist coalitions over farmland protection, even where common interests may unite these two constituencies.

Urban and suburban families in search of affordable housing are the driving force that fuels farmland conversion. While polls show that many city residents support saving farmland for the greenspace that open landscapes provide, city dwellers are often unprepared for the realities of living next door to a farm. Once they move in next to farming operations - unless there is a "right to farm" ordinance such residents may file nuisance complaints about the noise, odors and other consequences of living on the ag-urban edge, further pressuring farmers to get out and sell the land for development. Often suburban community activists use "environmental" arguments to battle higher-density housing and mixed-use developments, thereby perpetuating low-density sprawl land-use patterns that consume more farmland.

Finally, urban water suppliers have a direct interest in expanding the supply of water available to serve growing cities. Acquiring water from agriculture in many cases is the path of least resistance.

\section{Conclusions}

For meaningful farmland protection to be enacted in California, the farm community itself must be more united and aggressive in advocating for protection. In this, the work of the American Farmland Trust, individual county farm bureaus, and articulate leadership within the California Farm Bureau Federation and other statewide agricultural associations is critical.

There are reasons to be cautiously optimistic that a statewide coalition to protect farmland could emerge in California.

In an effort to build consensus, Central Valley growers and industry representatives have recently formed the Agricultural Task Force, which has developed a package of policy positions on farmland and related issues.

Urban water interests could find value in an approach that would guar- 
antee a reliable water supply to both cities and farms, in return for farmers agreeing not to develop their land.

Local officials and businesses could benefit from efforts that combined farmland protection with incentives for infill development and redevelopment in existing urban areas, if they were coupled with fiscal reforms to compensate for the loss of tax receipts and to ease the competition with other communities over the revenues from new development.

However, only modest and incremental change is likely unless there is new political leadership in Sacramento that is willing to tackle the economic, social and environmental consequences of rapid farmland conversion in the face of the determined opposition of most of the land development industry.

S. Sanders is Director of the California Futures Network, a coalition of organizations promoting sustainable land use in California. From 1988 to 1998 he was staff consultant in the California Legislature, most recently Chief of Staff to Assemblymember Michael Sweeney (D-Hayward).

\section{References}

American Farmland Trust. 1989. Risks, Challenges and Opportunities: Agriculture, Resources and Growth in a Changing Central Valley. San Francisco, CA.

Goldman G. 1991. State agricultural policy. In: John J. Kirlin, ed., California Policy Choices, Vol. 7. Los Angeles/Sacramento: School of Public Administration, University of Southern California. p183-97.

Grossi RE. "A Plan to Halt Loss of State's Farmland," San Francisco Chronicle, June 12, 1993.

Heim M. 1997. Which counties are projected for the most growth?" Sacramento: Demographic Research Unit, California Department of Finance.

Misczynski D. 1987. "The fiscalization of land use." In: John J. Kirlin, ed., California Policy Choices, Vol. 3. Los Angeles/Sacramento: School of Public Administration, University of Southern California. p. 73-105.

Nisbet B. 1993. Conserving the land that feeds us." 139-53. In: Tim Palmer, ed., California's Threatened Environment: Restoring the Dream. Planning and Conservation League Foundation.

Reisner M. 1997. Water Policy and Farmland Protection: A New Approach to Saving California's Best Agricultural Lands. American Farmland Trust, Washington, D.C.

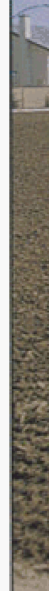

1itiv

As cities expand, urban residents are coming into closer contact with agriculture, as shown here near Modesto.

\section{Conflicts arise on the urban fringe}

\author{
Mary E. Handel
}

The frequent expansion of urban edges presents a challenge for California agriculture as the state's rich farmland base is consumed by nonfarm development. Some issues of conflict emerge as a part of the struggle for limited resources while others are related to the proximity of urban development and agriculture. Other conflicts reflect the urban resident's and farmer's different perspectives on the purpose or value of farmland. Local governments need to establish firm urbangrowth boundaries, create buffers between agriculture and urban land uses, and zone to eliminate incompatible land uses in agricultural areas. For its part, the agricultural community needs to educate the urban public to help them understand why particular farm management practices are necessary.
7 he conflict between urban and ag1 ricultural land uses is intensified by the frequent expansion of urban edges into farmland. These unstable urban edges cause problems because urban residents and farmers have different perspectives on the purpose or value of farmland. Approaches to reducing this conflict include establishing firm urban-growth boundaries and better buffers to separate urban and agricultural land uses, eliminating incompatible uses in agricultural zones, and increasing the nonfarm public's understanding of farm management practices. These findings are from a study of urban/agricultural conflict and specific approaches that local governments have taken to reduce or eliminate the conflict in 16 California counties and several cities therein (Handel 1994).

California is the nation's leading agricultural producer and most populous state at 33.2 million and growing. Adding more than half a million people to the state each year increases the pressure daily for ur- 